\title{
A CUTIN FLUORESCENCE PATTERN IN DEVELOPING EMBRYOS OF SOME ANGIOSPERMS
}

\author{
EWA SZCZUKA, BOHDAN RODKIEWICZ \\ Plant Anatomy and Cytology Department, \\ Institute of Biology, Maria Curie-Skłodowska University, \\ Akademicka 19, Lublin, Poland
}

\begin{abstract}
A cuticle visualized by auramine $\mathrm{O}$ fluorescence appears on the developing embryos of 9 species belonging to Cruciferae, Caryophyllaceae, Plantaginaceae, Linaceae and Papilionaceae.

In the investigated species the formation and extent of fluorescing and non-fluorescing embryonic areas follow a similar pattern. At first the cutin fluorescing layer is formed on the apical part of the proembryo without delimited protoderm. This layer extends and at the late globular stage envelops the embryo proper, except for a cell adjoining the suspensor. Fluorescing cutin persists during the heart stage but disappears from the torpedo embryo. During these stages there is no cutine fluorescence on suspensorial cells.

Continuous cutin fluorescence appears again on the surface of the whole embryo by the late torpedo stage. Then fluorescence disappears from the radicular part of U-shaped embryos, but persists on the shoot apex, cotyledons and at least on the upper part of hypocotyl.

It is assumed that polarization and nutrition of the embryo may be influenced by cuticular changes.
\end{abstract}

KEY WORDS: embryonic cutin, angiosperm embryogenesis.

\section{INTRODUCTION}

An electron dense cuticular layer was shown by electron microscopy on the early embryos of angiosperms. Such a distinct layer is present on heart-shaped embryos of Helianthus annuus (Newcomb, 1973) and on globular embryos of Linum catharticum (D'Alascio- Deschamps, 1978). In Reseda lutea globular embryos, the appearance of a cuticle coincides with the cellularization of endosperm. The cuticle persists on the heart-shaped embryos and later gradually disappears from growing embryos (Yakovlev and Tshaban, 1979). A very thin cuticle was noticed on the torpedo embryo of Daucus carota (Timmers, 1993). In Glycine max a thin cuticle is formed over the surface of the embryo proper, immediately before the cotyledons are initiated and persists in later stages of embryogenesis, but is absent around the suspensor (Chamberlin et al. 1993).

A changing pattern of fluorescing cutin distribution was shown in developing embryos of some angiosperms (Rodkiewicz et al. 1994).

Cutin fluorescence appears on the apical part of the globular embryos of Stellaria (dicots) and Alisma (monocots). Later the fluorescing layer envelops globular and heart-shaped embryos, but does not extend over the suspensor. Fluorescence disappears from torpedo embryos and appears again in the late torpedo stage (Szczuka et al. in press).

This paper is mainly concentrated on fluorescing cutin distribution on torpedo and U-shaped embryos of several dicot species.

\section{MATERIAL AND METHODS}

Proembryos, heart-shaped, torpedo and U-shaped embryos were dissected from living ovules of Capsella bursa-pastoris (L.) Med., Iberis umbellata L., Sinapis alba L., (Cruciferae), Stellaria media Vill. and Melandrium album (Mill.) Garcke (Caryophyllaceae), Pisum sativum L. and Lathyrus vernus (L.) Bernh. (Papilionaceae), Linum usitatissimum L. (Linaceae), Plantago media L. (Plantaginaceae). In order to find cutin fluorescence, the dissected embryos were placed into 0.01 per cent auramine $\mathrm{O}$ in $0.05 \mathrm{M}$ Tris/ $\mathrm{HCl}$ buffer, $\mathrm{pH} 7.2$ and investigated in a fluorescence microscope with a $400 \mathrm{~nm}$ excitation light (Heslop-Harrison, 1977). In this method yellow fluorescence is given by cuticular lipids (Maheshwaran and Williams, 1985).

For electron microscopy, embryos of Stellaria media, fixed in $3.5 \%$ glutaraldehyde in $0.05 \mathrm{M}$ cacodylate buffer at $\mathrm{pH} 7$, were embedded in Spurr's resin. Ultrathin sections stained with uranyl acetate and lead citrate were examined with the EM.

\section{OBSERVATIONS}

A fluorescing area of cutin at first appears on the apical region of proembryo consisting of several cells (Figs 1 and 2).

This area remains on the globular embryo with delimitated protoderm (Figs 3 and 4). There is no fluorescence on outer protodermal walls outside the apical region and on suspenso- 

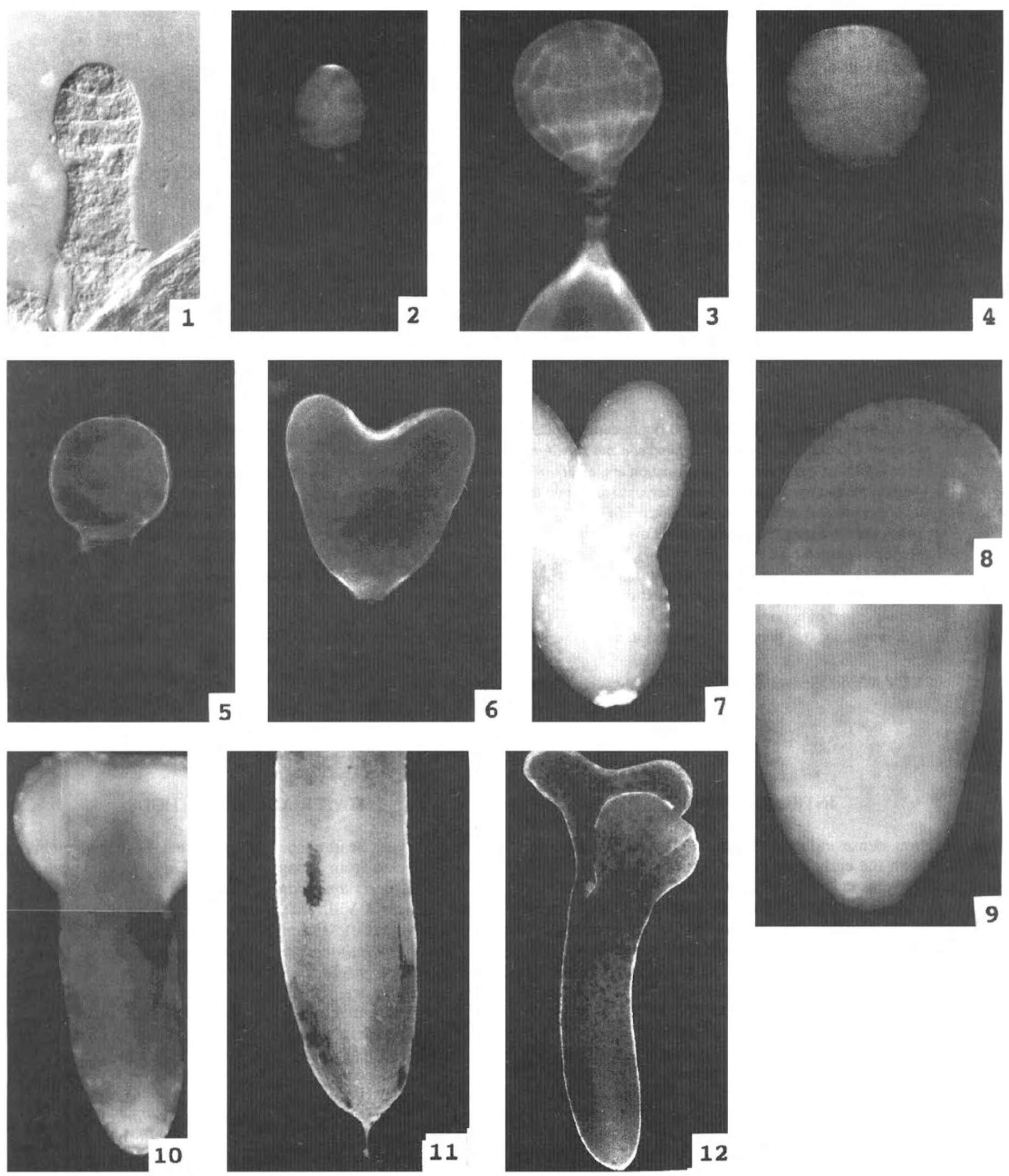

Figs 1-4. Stellaria proembryos, x 160; 1. About ten-celled proembryo, Nomarski microscope. 2. The same proembryo as in Fig. 1. Weak cutin fluorecence on the apical surface. 3. Proembryo just after protoderm differentiation. Cellulosic walls fluoresce after calcofluor staining. Suspensor with a part of large basal cell visible. 4. Similar proembryo as in Fig 3. with fluorescing cutin on the apex.

Figs 5-9. Capsella embryogenesis. Cutin fluorescence. 5. Globular embryo with not fluorescing suspensor, x 240; 6 . Heart-shaped embryo with not fluorescing suspensor, x 200; 7. Early torpedo-shaped embryo, (suspensor disintegrating), small areas of cutin fluorescence, x 200;

8. Middle torpedo stage; upper part of cotyledon - no distinct cutin fluorescence, x 350; 9 . Torpedo stage - radicula without cutin fluorescence, x 350 .

Figs 10-12. Sinapis embryogenesis. Very distinct fluorescence of the embryo surface. 10. Middle torpedo, x $60 ; 11$. Hypocotyl and radicle in late torpedo stage, x 60; 12. Late torpedo stage, x 30 . 

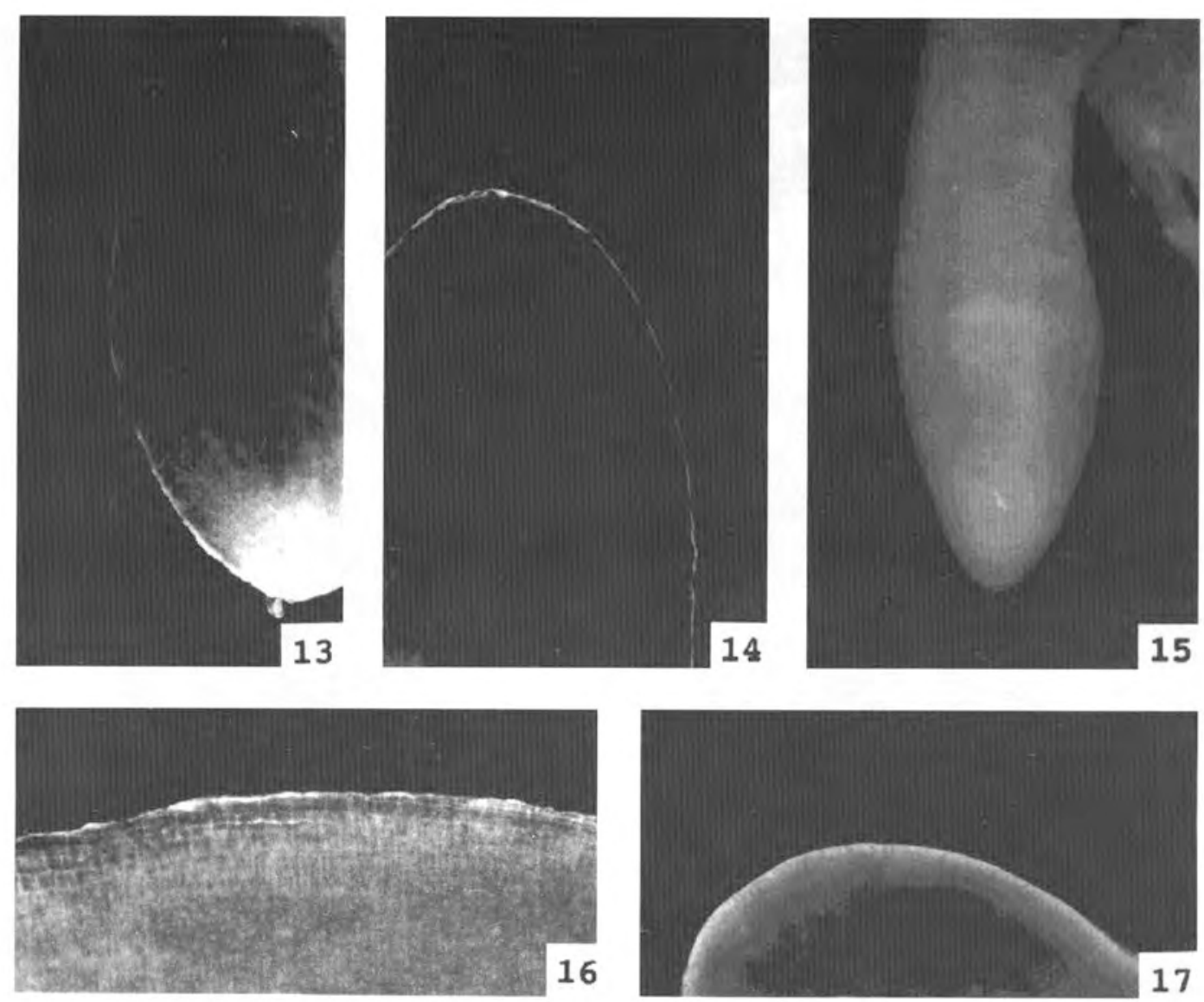

Figs 13-17. Capsella embryo cutin fluorescence. 13 and 14. radicular and cotyledonar regions at late torpedo stage embryo of Capsella, x 60; 15. Radicular region of U-shaped embryo, x 50; 16. Upper part of curved hypocotyl, x 60; 17. Part of cotyledon in Ushaped embryo of Iberis - cutin fluorescence, x 50;

rial cell walls (Fig. 4). Later fluorescing cutin occurs on the whole protoderm surface of the globular embryo except the cell adjoining the suspensor which also gives no cutin fluorescence (Fig. 5). In a heart-shaped stage fluorescing cutin envelops the embryo proper, but does not extend on the suspensor (Fig. 6).

Fluorescing and non-fluorescing cell walls differ structurally. The protodermal fluorescing walls of the late globular and heart-shaped embryos are covered by an electron-dense cuticular layer (Figs 19, 20, 23, 24 and 25) while cell walls of an early globular embryo and suspensor are homogenously dense (Figs 18, 21 and 22).

The fluorescing layer enveloping embryo proper disappears during transition from heart-shaped to torpedo stages (Figs 7 , $8,9,26$ and 27)and occurs again on the late torpedo embryo (Figs 10,11, 12 and 14). Fluorescence is especially strong on the radicular apex (Fig. 13). Later, in a U-shaped embryo the radicle and lower part of hypocotyl give no fluorescence (Fig. $15)$, while it is displayed on the cotyledons, apical meristem and upper part of hypocotyl (Figs 16 and 17). These regions remain fluorescing in a maturing embryo.

\section{DISCUSSION}

A cutin layer fluorescing after auramine $\mathrm{O}$ staining is formed on developing embryos of several species of dicotyledonous and one species of monocotyledonous plants (Rodkiewicz et al. 1994; Szczuka et al.). A schematic representation of cutin localization on a developing dicot embryo is presented in Fig. 28. The first fluorescing cuticule appears on the apical part of proembryo, just before the delimitation of protoderm. This cuticle is only slightly extended immediately after protoderm formation. Later it envelops the entire multicellular globular embryo proper, but not the suspensor. This pattern of cuticle localization persists in the heart stage. The fluorescing cuticle disappears during transition to the torpedo stage or in the early torpedo embryo, but appears again on the entire embryo by the end of the torpedo stage. Subsequently in the Ushaped embryo the radicular part does not give cutin fluorescence. This cutin fluorescence pattern lasts during the embryo maturation stage.

A cuticle formed over the surface of an embryo may be impervious to solute exchange, as sugested by Chamberlin et al. (1993) or at least decreases this exchange between the embryo and endosperm. The cuticle's presence over the embryo proper and its absence on the suspensor supports the view that in a number of angiosperms the suspensor plays an active role as an important route for the transport of substances into the early embryo (Yeung and Meinke, 1993); Cionini, 1987; Brady and Combs, 1988; Nagl, 1990; Natesh and Rau, 1984). There are, however, species with embryos without a suspensor or with a highly reduced suspensor.

Obliteration of the suspensor in the late heart and torpedo stages apparently coincides with or is followed by disappearance of fluorescing cutin. Then the torpedo embryo should absorb materials directly from the endosperm. It was shown by several authors that after transition from suspensorial to 

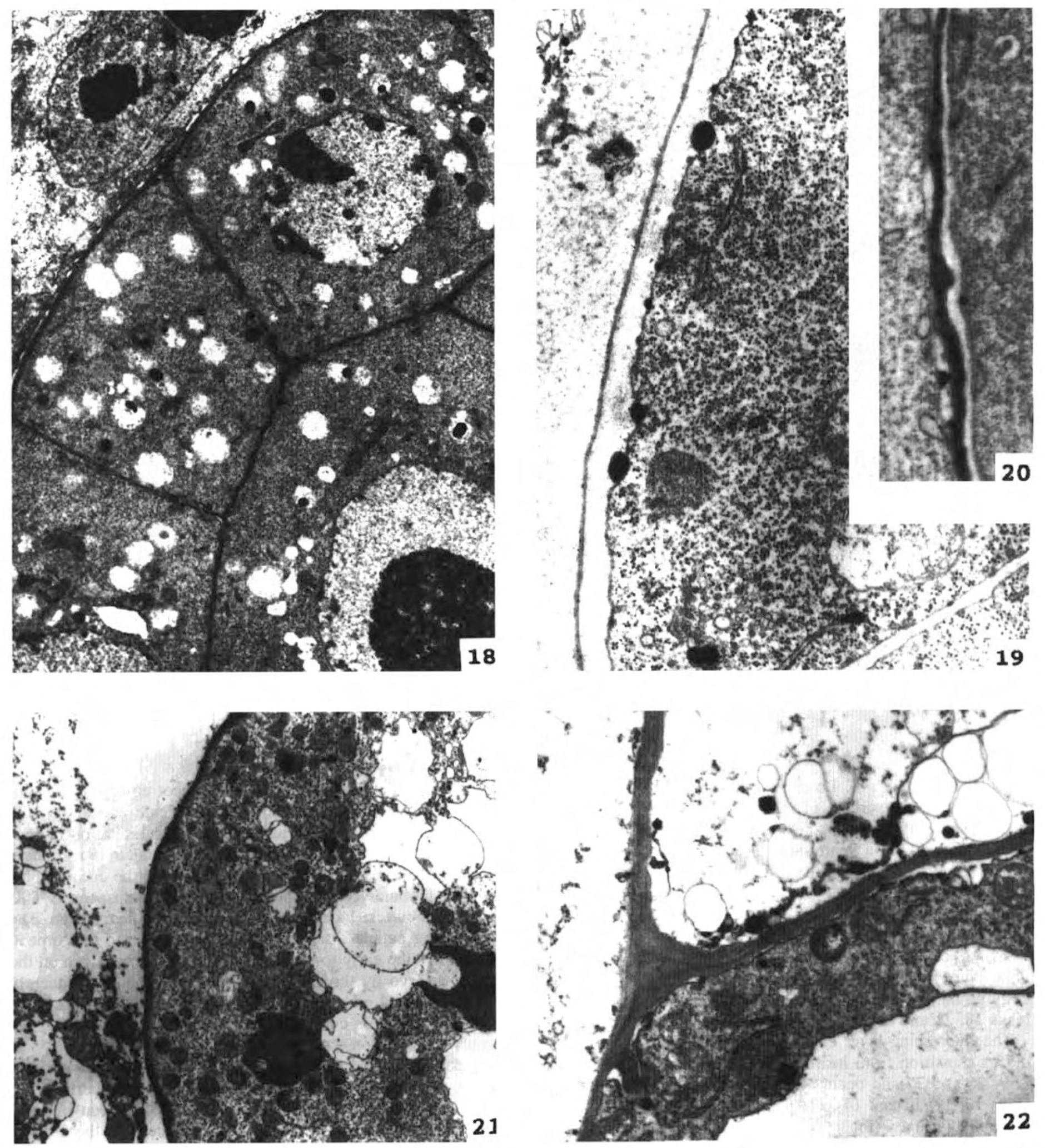

Figs 18-22. Stellaria embryo proper and suspensor. 18. Protodermal cell wall of globular embryo. Homogeneous thin outer cell walls, x 5000; 19. Late globular embryo. Outer cell wall with distinct cuticular layer, x 20000; 20. Globular embryo older than in fig. 19. Outer cell wall with very thick cuticular layer, x 16000; 21. Basal cell of a globular embryo suspensor, x 3000; 22 . Cell walls of a heartshaped embryo suspensor, x 7000 . 

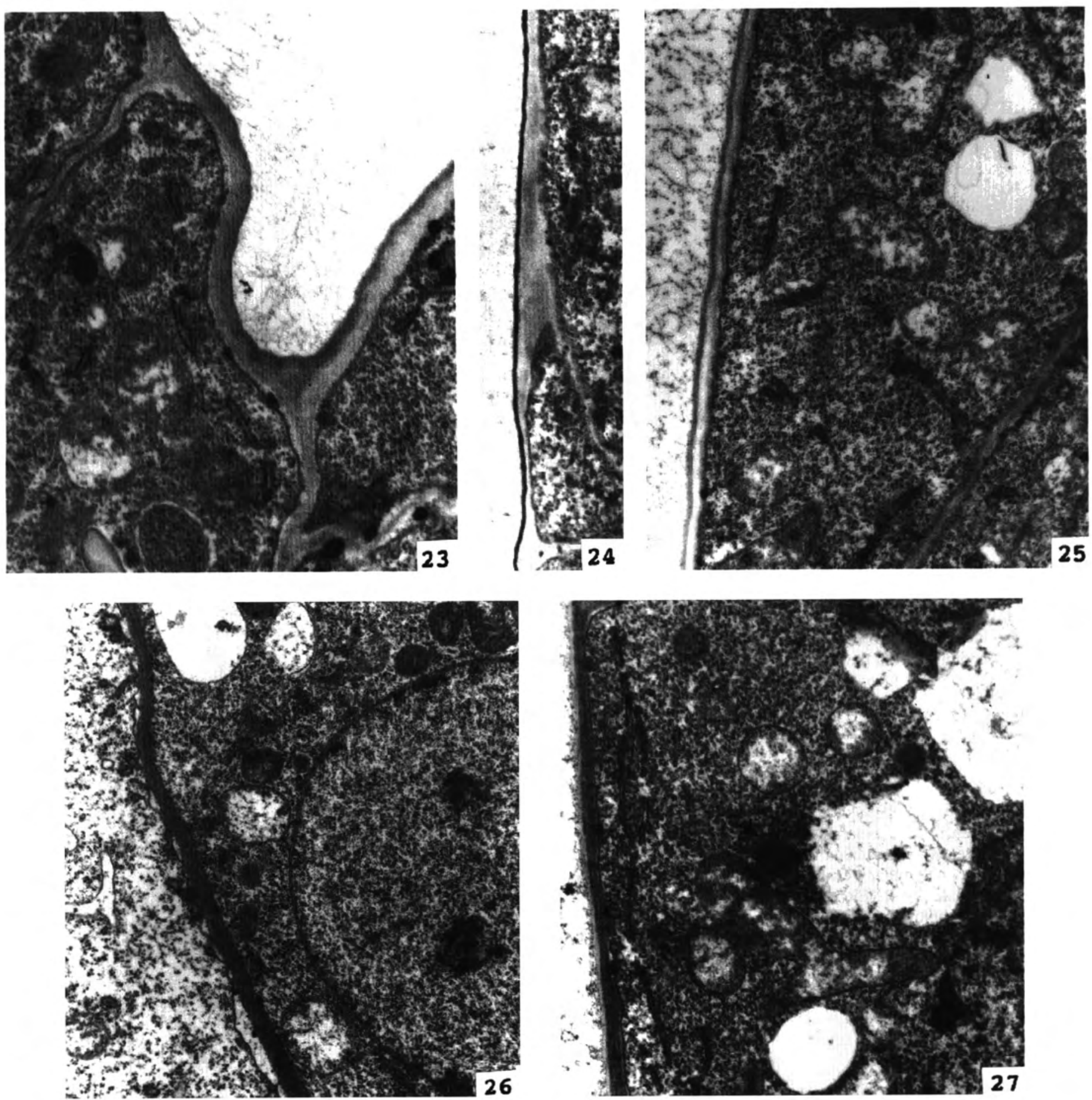

Figs 23-27. Stellaria embryos. 23. Cuticle on the apical part of a heart-shaped embryo, x 14000; 24 and 25 . Cuticule on the side walls of a heart-shaped embryo, 24. x 6000; 25. x 11000; 26 and 27. Torpedo stages. Cell walls without distinct cutin layer, 26. x 11500; $27 . \times 11000$.

surface nutrition, the cotyledons appear to be the major uptake regions of the embryo (Erdelska, 1984; Yeung, 1980; Johansson and Walles, 1993; Johansson, 1994).

During the late torpedo stage or during transition from the torpedo stage to the next stage of embryogenesis, the embryo forms a new fluorescing layer over its entire surface. The layer of cutin should to some extent isolate the embryo at this stage from the endosperm and limit exchange of solutes. This isolation may act as a factor for induction of some maturation processes in the embryo. When these processes have begun, the cutin layer on the radicular part is degraded and communication between embryo and endosperm is partially restored.

\section{ACKNOWLEDGEMENTS}

We thank professor Thomas S. Gladsky of Eastern Illinois University for linguistic assistance. 

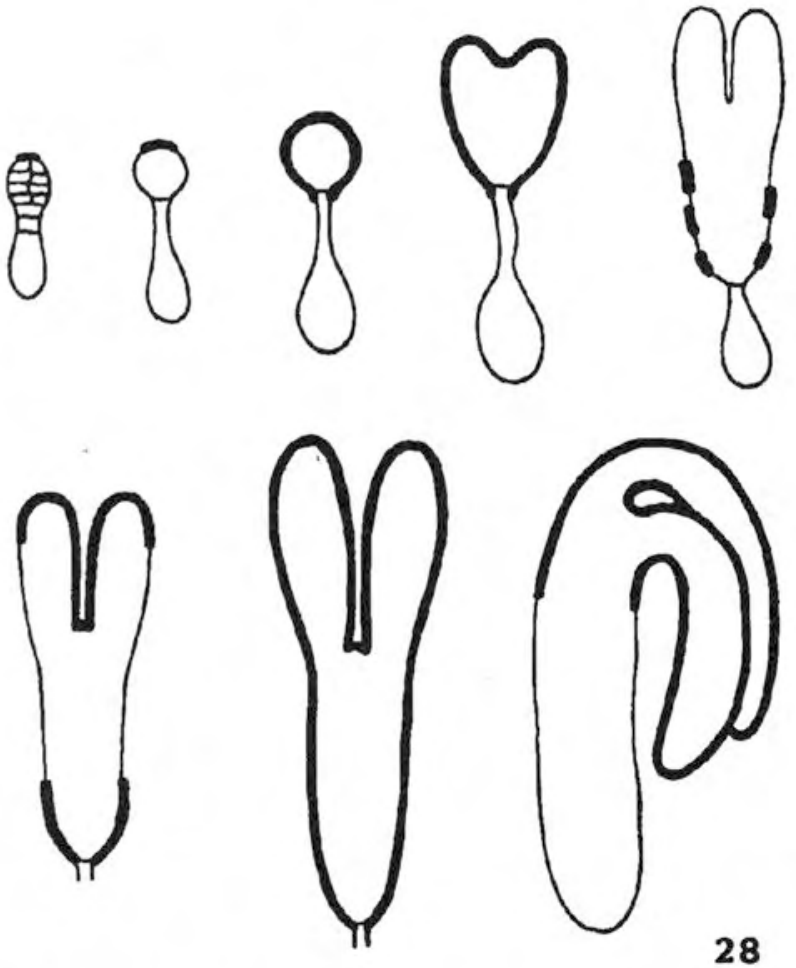

28

Fig. 28. Localization of fluorescing cutin (thick line) on a developing embryo. The cells of the embryo proper and suspensor are only shown in the first picture. The pattern of fluorescing cutin distribution is mainly compiled from the data on nine dicot species.

\section{LITERATURE CITED}

BRADY T., COMBS S.H., 1988. The suspensor is a major route of nutriens into proembryo, globular and heart stage Phaseolus vulgaris embryos. In: Sexual reproduction in higher plants. Cresti M., Gori P., Pacini E. (eds). Springer Verl. Berlin, pp. 419-424.

CHAMBERLIN M.A., HORNER H.T., PALMER G.R., 1993. Nutrition of ovule, embryo sac and young embryo in soybean: an anatomical and autoradiographic study. Can. J. Bot. 71: 1153-1168.
CIONINI P.G., 1987. The suspensor and its role in embryo development in Phaseolus (Papilionaceae): a review. Atti Soc. Toscana Sci. Nat. Mem. ser. B 94: 151-161.

D'ALASCIO-DESCHAMPS R., 1978. Etude ultrastructurale et cytochimique de la jouction albumen-embryon pour divers stades du development Soc. bot. Fr., Actualites Bot. 1/2: 273-277.

ERDELSKA O., 1984. Some structural features of the embryo/endosperm interaction in angiosperms. In: Sexual reproduction in seed, plants, ferns and mosses. Willemse M.T.M., Van Went J.L. (eds). Pudoc Wageningen, pp. 168-170.

HESLOP-HARRISON Y., 1977. The pollen-stigma interaction: pollen tube penetration in Crocus. Ann. Bot. 41: 913-922.

JOHANSSON M., 1994. Morphogenesis and functional anatomy of the ovule in broad bean (Vicia faba L.). PhD Thesis, Akademitryck Ab, Edsbruk

JOHANSSON M., WALLES B., 1993. Functional anatomy of the ovule in broad bean (Vicia faba L.) I. Histogenesis prior to and after pollination. Int. J. Plant Sci. 154: 80-8.

MAHESHWARAN G., WILLIAMS E.G., 1985. Origin and development of somatic embrioids formed directly on immature embryos of Trifolium repens. Ann. Bot. 56: 619-630.

NAGL W., 1990. Translocation of putrescine in the ovule, suspensor and embryo of Phaseolus coccineus. J. Plant Physiol. 136: 587-591.

NATESH S., RAU M.A., 1984. The embryo. In: Johri B.M. (ed.). Embryology of Angiosperms. Springer Verl. Berlin, pp. 377-443.

NEWCOMB W., 1973. The development of the embryo sac of sunflower Helianthus annuus after fertilization. Can. J. Bot. 53: 879-890.

RODKIEWICZ B., FYK B., SZCZUKA E., 1994. Chlorophyll and cutin in early embryogenesis in Capsella, Arabidopsis and Stellaria investigated by fluorescence microscopy. Sex. Plant Reprod. 7: 287-289.

SZCZUKA E., FYK B., RODKIEWICZ B., 1995. Cutin and chlorophyll fluorescence in developing embryos of some angiosperms. (in press)

TIMMERS A.C.J., 1993. Imaging of polarity during zygotic an somatic embryogenesis of carrot (Daucus carota L.) PhD Thesis, Cip-Gegevens Koninklijke Bibliotheek, Den Haag pp. 123.

YAKOVLEV M.S., TSHABAN J.A., 1979. Ultrastructural aspects in embryogenesis of Reseda lutea. (in Russian) In: Yakovlev M.S. (ed.). Aktualnye voprosy embriologii pokrytosemennykh Nauka, Leningrad, pp. 96-104.

YEUNG E.C., 1980. Embryogeny of Phaseolus: the role of the suspensor. Z Phlanzenphysiol. 96: 17-28

YEUNG E.C., MEINKE D.W., 1993. Embryogenesis in angiosperms: development of the suspensor. Plant Cell 5: 1371-1381

\section{WZÓR ROZMIESZCZENIA FLUORYZUJĄCEJ KUTYNY W EMBRIOGENEZIE ROŚLIN OKRYTOZALĄŻKOWYCH}

\section{STRESZCZENIE}

Zarodki 9 gatunków z rodzin: Cruciferae, Caryophyllaceae, Plantaginaceae, Linaceae i Papilionaceae obserwowano w mikroskopie elektronowym i fluorescencyjnym z filtrem wzbudzającym $400 \mathrm{~nm}$.

Zarodki wszystkich, badanych gatunków po zabarwieniu auraminą O wykazują fluorescencję kutyny. Fluoryzująca warstwa kutyny pojawia się najpierw na wierzchołku prazarodka; następnie na powierzchni zarodka globularnego i okrywa cały sercowaty zarodek właściwy, po czym zanika w fazie torpedowatej. Nie ma kutyny na wieszadełku.

Ciągła warstwa fluoryzującej kutyny pojawia się znów na całym zarodku pod koniec stadium torpedowatego. Później fluorescencja znika z powierzchni korzenia zarodkowego; pozostaje na merystemie wierzchołkowym pędu, liścieniach i górnej części hipokotyla.

Można wnioskować, że zmiany w rozmieszczeniu kutykuli wpływają na polaryzację i odżywianie zarodka. 